\title{
A Study on Interaction between Overfall Types and Scour at Bridge Piers with a Moving-Bed Experiment
}

\author{
Wei-Lin Lee ${ }^{1}{ }^{(}$, Chih-Wei Lu ${ }^{2, *}$ and Chin-Kun Huang ${ }^{1}$ \\ 1 Department of Hydraulic and Ocean Engineering, National Cheng Kung University, Tainan 701401, Taiwan; \\ glaciallife@gmail.com (W.-L.L.); ckhuang@mail.ncku.edu.tw (C.-K.H.) \\ 2 Department of Civil and Construction Engineering, National Taiwan University of Science and Technology, \\ Taipei 106335, Taiwan \\ * Correspondence: cwlu@mail.ntust.edu.tw; Tel.: +886-2-2737-6563
}

check for

updates

Citation: Lee, W.-L.; Lu, C.-W.;

Huang, C.-K. A Study on Interaction between Overfall Types and Scour at Bridge Piers with a Moving-Bed Experiment. Water 2021, 13, 152. https://doi.org/10.3390/w13020152

Received: 15 December 2020 Accepted: 8 January 2021

Published: 11 January 2021

Publisher's Note: MDPI stays neutral with regard to jurisdictional clai$\mathrm{ms}$ in published maps and institutional affiliations.

Copyright: (C) 2021 by the authors. Licensee MDPI, Basel, Switzerland. This article is an open access article distributed under the terms and conditions of the Creative Commons Attribution (CC BY) license (https:// creativecommons.org/licenses/by/ $4.0 /)$.

\begin{abstract}
River slopes can be changed due to an extreme event, e.g., a large-scale earthquake. This can uplift a riverbed greatly and thereby change the behavior of the river flow into a free or submerged overfall. Corresponding damage, including extreme erosion, on bridge piers located in the river can take place due to the aforementioned flow conditions. A reconstructed bridge pier in the same location would also experience a similar impact if the flow condition is not changed. It is important to identify these phenomena and research the mechanism in the interaction between overfall types and scour at bridge piers. Therefore, this paper is aimed at studying a mechanism of free and submerged overfall flow impacts on bridge piers with different distances by a series of moving-bed experiments. The experiment results showed clearly that bridge pier protection requires attention particularly when the pier is located in the maximum scour hole induced by the submerged overfall due to the $\mathrm{z}$ directional flow eddies. In many other cases, such as when the location of the bridge pier was at the upstream slope of a scour hole induced by a flow drop, a deposition mound could be observed at the back of the pier. This indicates that, while a pier is at this location, an additional protection takes place on the bridge pier.
\end{abstract}

Keywords: bridge pier; overfall; scour; landform change impact on pier

\section{Introduction}

Unexpected free or submerged overfall conditions in a river flow can occur due to a force within the earth that causes the riverbed to uplift. The changed condition of river flow could have an impact on the safety of downstream river structures. A major earthquake that occurred in 21 September 1999 dramatically changed many landforms in central Taiwan, such as a local rise in the Da-Ja River inducing a flow drop in the riverbed. This flow drop is very close to the Pai-Furn bridge pier and could induce additional erosion. Figure 1a demonstrates a bridge that was damaged in the 921 Earthquake in 1999 in Taiwan and the surrounding river bed was significantly affected. The newly constructed bridge was completed in less than 2 years due to the importance for transportation (shown in Figure 1b). However, it can be seen in Figure 1c that the bridge pier was again exposed to river flow in six years due to significant nearby scour. Figure $1 b, c$ display that the riverbed level had been apparently lowered down $4.5 \mathrm{~m}$ deep near the pier with a diameter of $3.6 \mathrm{~m}$. 


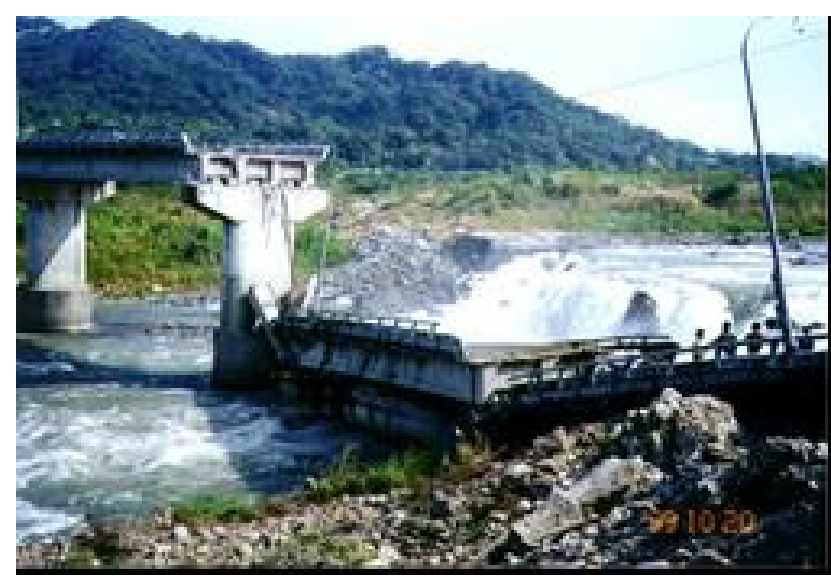

(a)

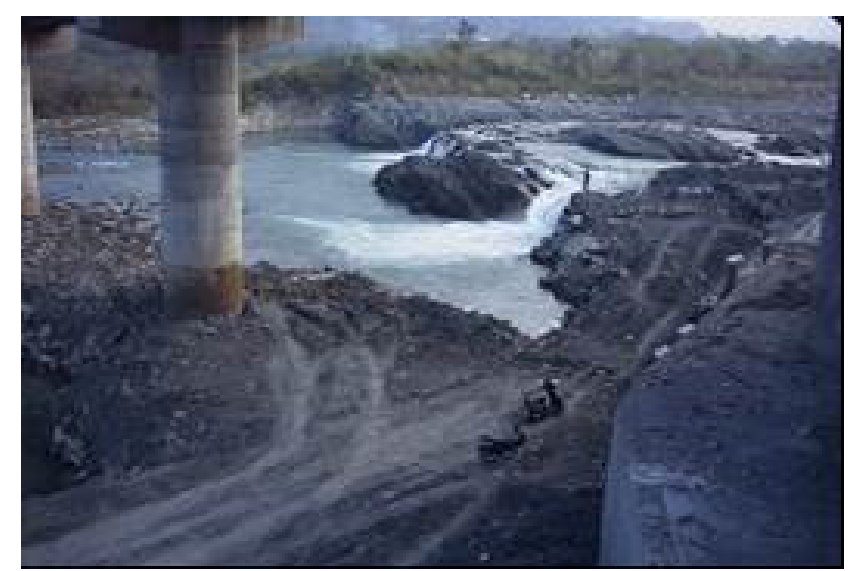

(b)

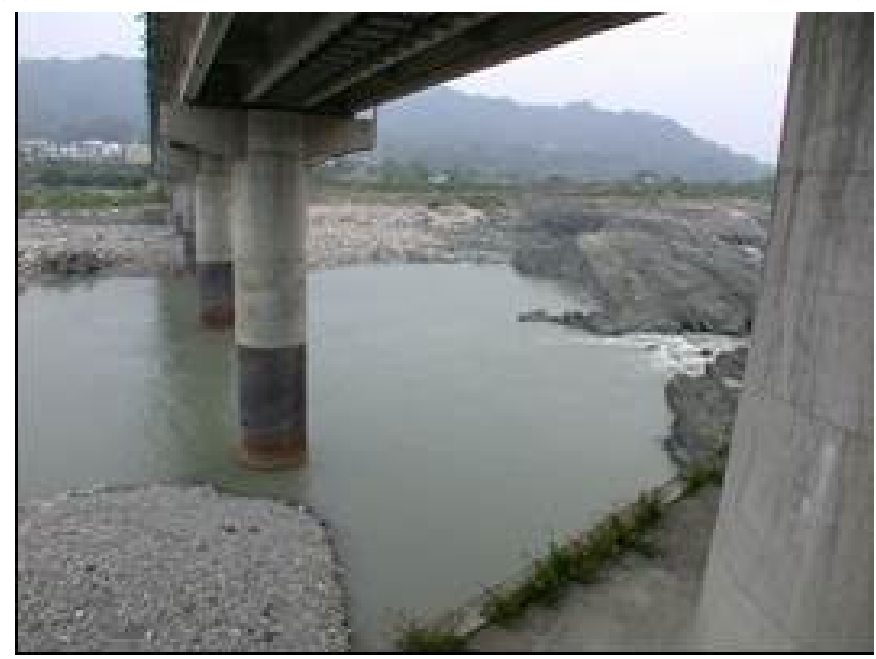

(c)

Figure 1. (a) Changed river bed and damaged bridge due to the 921 Earthquake in 1999; (b) Newly constructed bridge in the same location; (c) Water drop and local scour at the bridge piers.

Many researchers devoted themselves to studying local scour below drop structures and at bridge piers (Dey 2014) [1]. Some researchers focused on the local scour below drop structures; for example, Schoklitsch (1932) has been the pioneering researcher and proposed an empirical relationship to estimate the equilibrium scour depth for flow-over structures [2]. Moore (1943), Rand (1955), Akram (1979), and Little and Murphey (1982) studied the energy change due to the drop [3-6]. Smith and Strang (1967) found that the profile change of a riverbed was strongly affected by the size of the river bed materials [7]. Mason and Arumugam (1985) reviewed the empirical formulas of equilibrium scour depth under a falling jet that started in 1932, and they proposed a modified formula that includes the effect of tailwater depth [8]. Hoffmans (1998) derived relations to predict the maximum scour depth in the equilibrium phase based on the Newton's second law of motion [9].

Hoffmans (2009) introduced an index to represent the strength of loose material and extended previous relations to predict the sum of the maximum scour depth and the tailwater depth [10]. D'Agostino and Ferro (2004) proposed an empirical formula to estimate the equilibrium scour depth of weir type drop structures based on the high crest of the weir and the flow depth over a weir [11]. Yager et al. (2012) extrapolated an approach to predict the scour depth and geometry of A-, U-, and W-shaped rock weirs from the case of two-dimensional flow [12]. Melville (2014) used a small-scale experiment to investigate the scour at a bridge foundation in the vicinity of a sluice gate and low wire [13]. 
With the aforementioned research, the effect of different types of drop structures, different conditions of approach flow, and different materials of sediment have been investigated, and varied empirical formulas for the characteristic of local scour due to the drop structure have been proposed. On the other hand, some researchers focused on the local scour at bridge piers; for example, Breusers et al. (1977) reviewed a series of literature regarding theory, model, and field data about the local scour around cylindrical piers and suggested a set of designs for protection against scour [14]. Ahmed and Rajaratnam (1998) reported that smooth, rough, and mobile beds impacted the flow features and pier scour [15]. Graf and Istiarto (2002) experimented with the equilibrium scour depth around a cylinder pier and investigated the vortex system around a cylinder pier based on measurement of the acoustic Doppler velocity profiler (ADVP) [16].

Dey and Raikar (2007) experimented with the developing scour depth around a cylinder pier and investigated the features of the vortex system in the intermediate and equilibrium stages [17]. Ataie-Ashtiani and Aslani-Kordkandi (2013) experimented with the developing scour depth around a single pier and two piers in tandem on a roughly flat bed and investigated the difference of flow features in the implemented experiments [18]. Euler et al. (2014) investigated the local scour in the vicinity of pillar-like objects through experimental studies and compared the results with field data [19].

These studies contribute to the flow feature impact on pier scour. Other studies focused on scoring features. For example, Baker (1980) derived a formula to estimate the equilibrium scour depth in front of a cylindrical bridge pier and compared the results with the results of Baker (1979), Breusers et al. (1977), and Chabert and Engeldinger (1956) [14,20-22]. Chiew and Melville (1987) proposed an empirical relationship that was related to the equilibrium depth scour, particle size of sediment, and flow condition, and compared their results with the findings of Chee (1982) and Melville (1984) [23-25]. Elliott and Baker (1985) investigated the feature of scour depth under the effect of lateral spacing between bridge piers [26]. Melville and Chiew (1999) indicated that the development of the equilibrium scour depth can be related with the size of the pier, size of the sediment, and approach flow velocity [27].

Sheppard et al. (2004) indicated that the wash load concentration impacts the scale of the equilibrium scour depth under clear-water conditions [28]. Ataie-Ashtiani and Beheshti (2006) derived an empirical relationship to estimate the maximum local scour depth for the pile group and compared their results with the reports of Melville and Coleman (2000) and Richardson and Davis (2001) [29-31]. Khosronejad et al. (2012) investigated the features of clear-water scour around the geometry of cylindrical, square, and diamond bridge piers through experiments and numerical simulation [32]. According to the aforementioned research, the mechanism of local scour at bridge piers has been investigated comprehensively by the theory, experiment, field data, and numerical model, and empirical formulas for the equilibrium depth scour at bridge piers have been proposed. However, there are few papers, to the authors' knowledge, focusing on the interaction between overfall types and scour at bridge piers.

This paper was focused on probing the mechanism of the scouring effect on piers considering the different bridge locations and a flow-drop-induced scour hole. Two types of overfall, which included the submerged type and free overfall type, were researched herein. In the submerged type, the velocity component in the vertical direction was relatively smaller and, therefore, gave a smaller effect on the riverbed scour. The free type of overfall, on the other hand, produced a strong velocity component in the vertical direction and induced a more dramatic riverbed change. It is necessary to discuss in detail the response of piers suffering these two types of overfall and to take these responses into consideration in engineering practice. 


\section{Procedure of the Experimental Work}

The configuration for the experiment flume equipped with a circulation flow system is shown in Figure 2a. The total length of the flume was $15 \mathrm{~m}$, the width was $1 \mathrm{~m}$, and slope of the flume bed was $1 / 1000$. The wall of the flume was $0.8 \mathrm{~m}$ in height composed of transparent tempered glass. A deeper part of the flume bed had $2 \mathrm{~m}$ length, $1 \mathrm{~m}$ width, and $0.4 \mathrm{~m}$ depth located at $7 \mathrm{~m}$ upstream from the scour development. A flat flume bed was provided with $4.4 \mathrm{~m}$ in length, which was 81 times the hydraulic radius of $5.4 \mathrm{~cm}$ for a fully developed flow. $H$ represents the difference in height from the water level upstream of the lifted platform to the tailwater level. $d_{\mathrm{s}}$ indicates the depth of scouring.

(a)

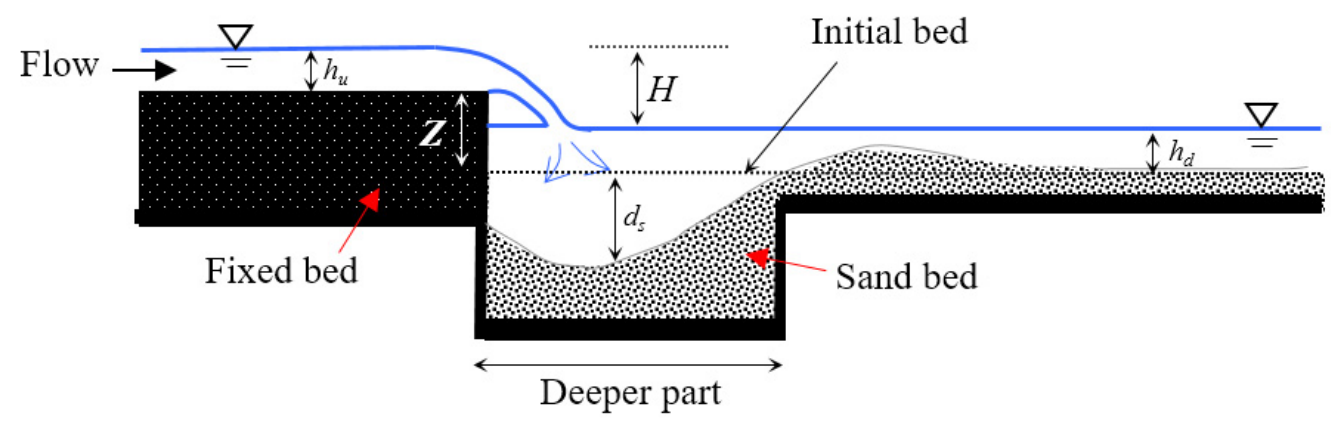

(b) Free overfall condition

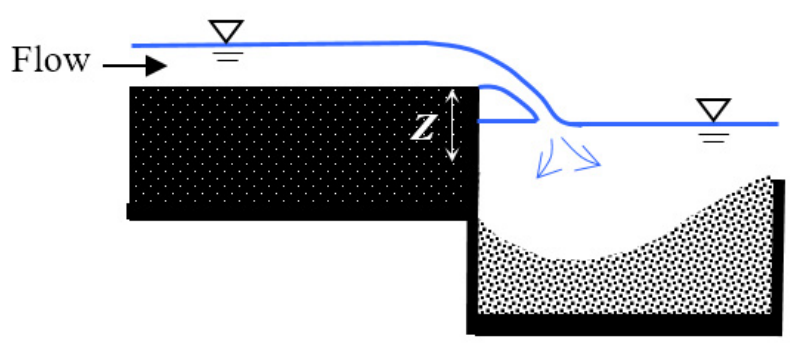

(c) Submerged overfall condition

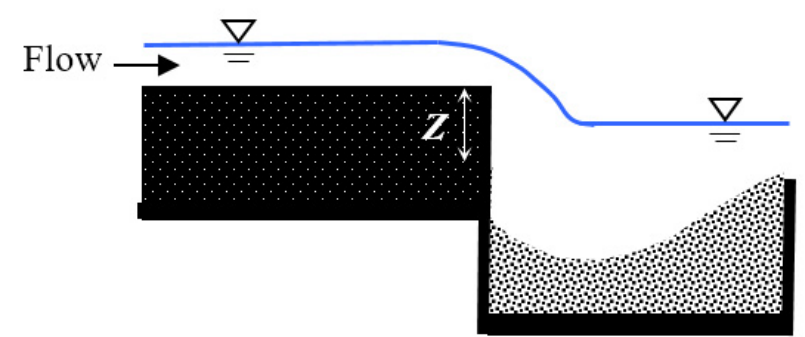

Figure 2. (a) Configuration of experiment flume. (b) Schematic of free overfall condition. (c) Schematic of submerged overfall condition.

For the sediment using in the experiment, we assumed that the river bed was composed of medium sand. The median diameter $\left(D_{50}\right)$ of sediments in this experiment was $0.46 \mathrm{~mm}$, and the standard deviation of the sediments $\left(\sigma_{g}\right)$ was 1.69. Randkivi and Ettema (1977) suggested that the $\sigma_{g}$ should be smaller than 1.3 to avoid the armor layer in the development of local scour [33]. The flume was paved using homogenous sediments at a $2.5 \mathrm{~cm}$ depth in the zone out of the scour area to provide a similar roughness in the alluvial bed.

This was a clear-water scour test. The experiment was designed so that the local scour occurred only due to the influence of the drop structure and pier. In other words, the clearwater flow could trigger scour in the moving-bed when there was no drop structure and pier in the experiment flume. Accordingly, the ratio of the designed velocity of approach flow $(V)$ and the critical mean approach flow velocity of the using sediment $\left(V_{c}\right)$ was given as 0.5. Melville and Sutherland (1988) suggested that the critical mean approach flow velocity $\left(V_{c}\right)$ can be estimated using following equation:

$$
\frac{V_{c}}{V_{* c}}=5.75 \times \log \left[5.53 \times \frac{h_{d}}{D_{50}}\right]
$$

where $h_{d}$ is the depth of the downstream flow, and $V{ }^{*_{c}}$ is the shear velocity of the using sediment [34]. Melville and Sutherland (1988) proposed a Shields chart for the threshold condition of uniform sediment in water, and the shear velocity was suggested as 
$0.018 \mathrm{~m} / \mathrm{sec}$ for using sediment [34]. To satisfy the aforementioned conditions, in the experiment, the boundary conditions of flow were: critical flow depth $h_{c}=2.4 \mathrm{~cm}$, upstream flow depth $h_{u}=5.4 \mathrm{~cm}$, upstream velocity $27.6 \mathrm{~cm} / \mathrm{sec}$, upstream Froude number $\mathrm{Fr}=0.38$, downstream flow depth $h_{d}=9.5 \mathrm{~cm}$, downstream velocity $(V) 15.9 \mathrm{~cm} / \mathrm{sec}$, and downstream Froude Number Fr $=0.16$.

The authors changed the difference in height between the river bed and the crest of flow-control structure $(Z)$ to produce two different conditions: free overfall and submerged overfall, with the same boundary conditions upstream and downstream, to study the interacting behaviors between the pier and overfall. The schematics of the free overfall and submerged overfall are shown in Figure $2 b, c$. The values of $Z$ were selected as 8 and $12 \mathrm{~cm}$ in which the submerged overfall took place at $Z=8 \mathrm{~cm}(H=3.9 \mathrm{~cm})$ with no air vent occurrence and the free overfall took place at $Z=12 \mathrm{~cm}(H=7.9 \mathrm{~cm})$ with air vent occurrence.

Melville and Chiew (1999) and Dey (2014) indicated that the approach flow can no longer move the sediment from the scour hole when the scour is at equilibrium in the clear-water condition [1,27]. Accordingly, the equilibrium time was selected based on the development process of the scour hole in the free overfall test, in which $83.5 \%$ of the $24 \mathrm{~h}$ erosion was reached in $5 \mathrm{~h}$ as shown in Figure 3. We also observed that the deposition of the dune downstream was segregated after $4 \mathrm{~h}$ of erosion due to the lack of sediment supplementation from upstream. This showed that the overfall energy was dispersed in the scour hole so that the erosion was reduced. Therefore, the scouring behavior in the fifth erosion hour was chosen for discussion in this paper.

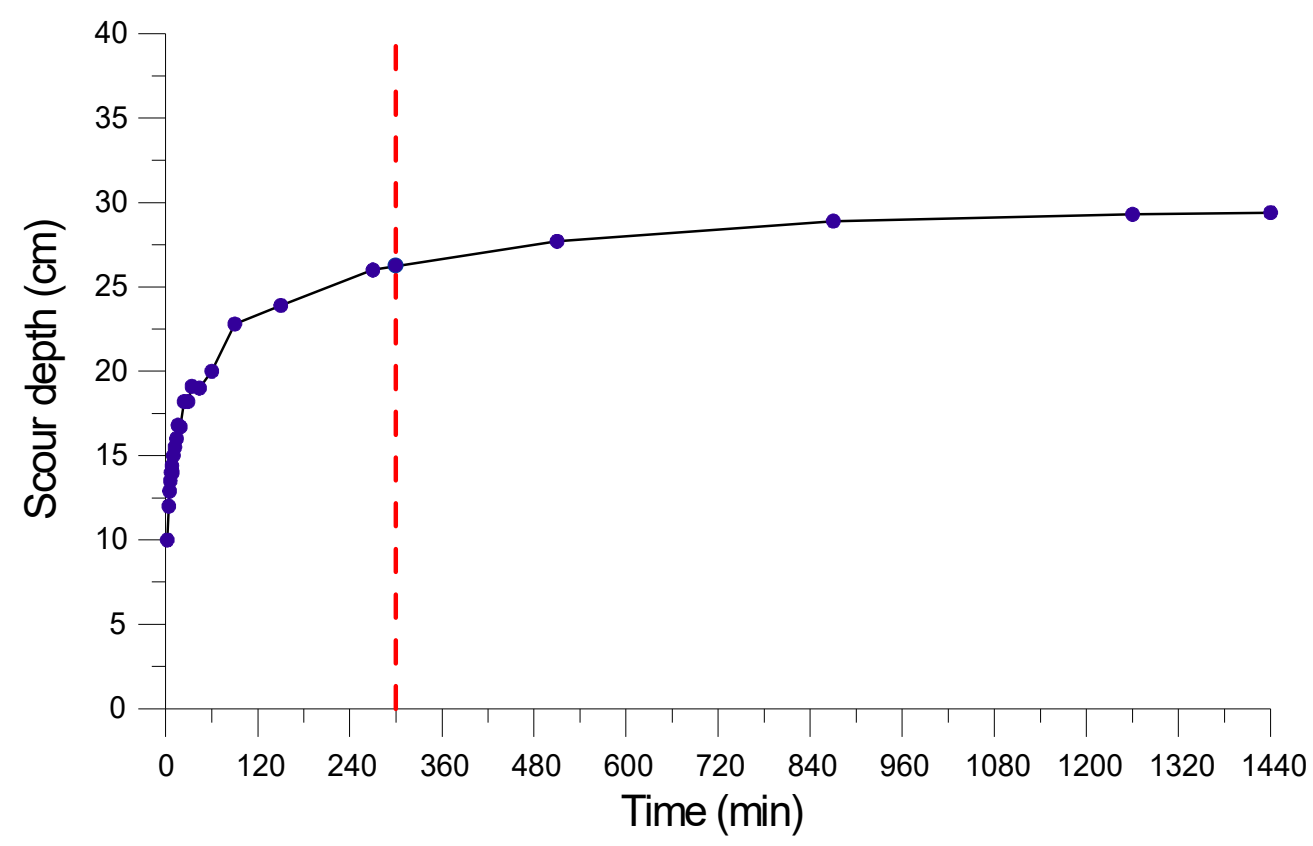

Figure 3. Development of the scouring process (the broken line was selected as the equilibrium hour).

A significant bed would be changed in the free overfall test; therefore, piers were installed at five locations:

1. At half distance between the maximum scour depth and upstream, which was $16 \mathrm{~cm}$ $\left(L_{a}\right)$ to the flow-control structure, namely Case A.

2. At the maximum scour depth, which was $32 \mathrm{~cm}\left(L_{b}\right)$ to the flow-control structure, namely Case B.

3. At half of the inclined slope of the scouring hole, which was $58.7 \mathrm{~cm}\left(L_{c}\right)$ to the flow-control structure, namely Case C.

4. At the boundary between the scouring hole and original bed, which was $85.5 \mathrm{~cm}\left(L_{d}\right)$ to the flow-control structure, namely Case D. 
5. At the deposition zone of the downstream, which was $130.8 \mathrm{~cm}\left(L_{e}\right)$ to the flow-control structure, namely Case E.

On the other hand, piers were installed at three different locations for the submerged overfall test:

1. At upstream, which was $17.3 \mathrm{~cm}\left(L_{f}\right)$ to the flow-control structure, namely Case F.

2. At the scouring hole, which was $46.4 \mathrm{~cm}\left(L_{g}\right)$ to the flow-control structure, namely Case G.

3. At the boundary between the scouring hole and original bed, which was $73.5 \mathrm{~cm}\left(L_{h}\right)$ to the flow-control structure, namely Case $\mathrm{H}$.

The above-mentioned cases are summarized in Table 1, and the schematic of the pier locations for free overfall and submerged overfall is shown in Figure 4. In addition, the free type and submerged type of overfall where no pier was installed in the experiment flume were also carried out and named "free overfall w/o pier" and "submerged overfall w/o pier", respectively. Lastly, a pier in the experiment flume was implemented without any type of overfall condition $(Z=0 \mathrm{~cm})$ and named "Pure Bridge".

Table 1. List of the locations of piers.

\begin{tabular}{cccccccccc}
\hline Type of Overfall & \multicolumn{4}{c}{ Free Overfall } & \multicolumn{4}{c}{$\begin{array}{c}\text { Submerged } \\
\text { Overfall }\end{array}$} \\
\hline Case & \multicolumn{1}{c}{$\mathbf{A}^{\mathbf{2}}$} & $\mathbf{B}^{\mathbf{3}}$ & $\mathbf{C}^{\mathbf{4}}$ & $\mathbf{D}^{\mathbf{5}}$ & $\mathbf{E}^{\mathbf{6}}$ & $\mathbf{F}^{\mathbf{2}}$ & $\mathbf{G}^{\mathbf{3}}$ & $\mathbf{H}^{\mathbf{4}}$ \\
\hline Height of overfall $(\mathrm{Z})$ & 12 & 12 & 12 & 12 & 12 & 8 & 8 & 8 \\
\hline $\begin{array}{c}\text { The distance from pier to } \\
\text { flow-control structure }\left(L_{i}\right)\end{array}$ & 16 & 32 & 58.7 & 85.5 & 130.8 & 17.3 & 46.4 & 73.5 \\
& $\left(L_{a}\right)$ & $\left(L_{b}\right)$ & $\left(L_{c}\right)$ & $\left(L_{d}\right)$ & $\left(L_{e}\right)$ & $\left(L_{f}\right)$ & $\left(L_{g}\right)$ & $\left(L_{h}\right)$ \\
\hline
\end{tabular}

${ }^{1}$ A-E: free overfall flow F-H: Submerged overfall flow. ${ }^{2}$ A and F: Pier located at the upstream slope of the flow-drop-induced scour hole. ${ }^{3} \mathrm{~B}$ and G: Pier located at the maximum scour point of the flow-drop-induced scour hole. ${ }^{4} \mathrm{C}$ and $\mathrm{H}$ : Pier located at the downstream slope of the flow-drop-induced scour hole. ${ }^{5} \mathrm{D}$ : Pier located at the edge of the flow-drop-induced scour hole. ${ }^{6} \mathrm{E}$ : Pier located far from the scour hole.

(a) Free overfall condition

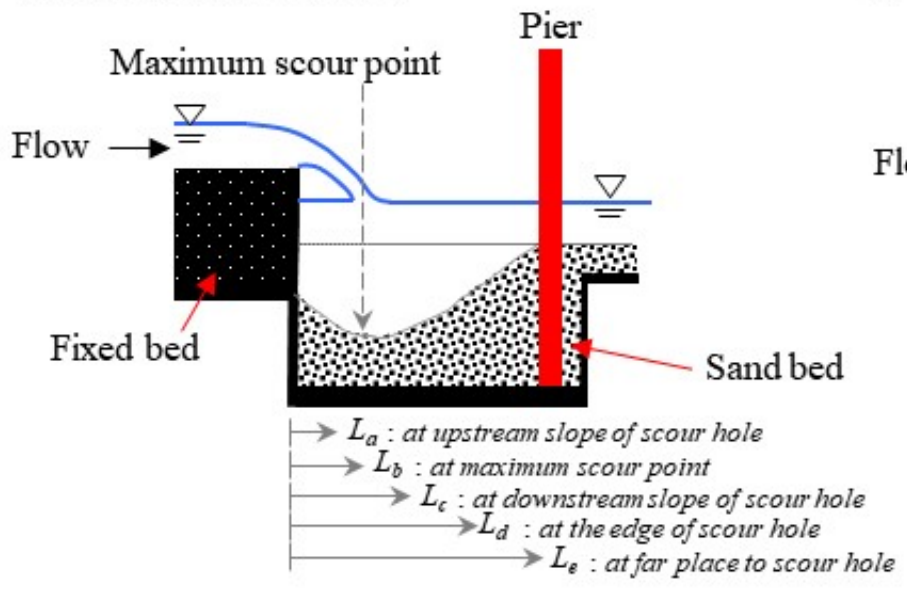

Distance of Pier $\left(L_{i}\right)$ (b) Submerged overfall condition

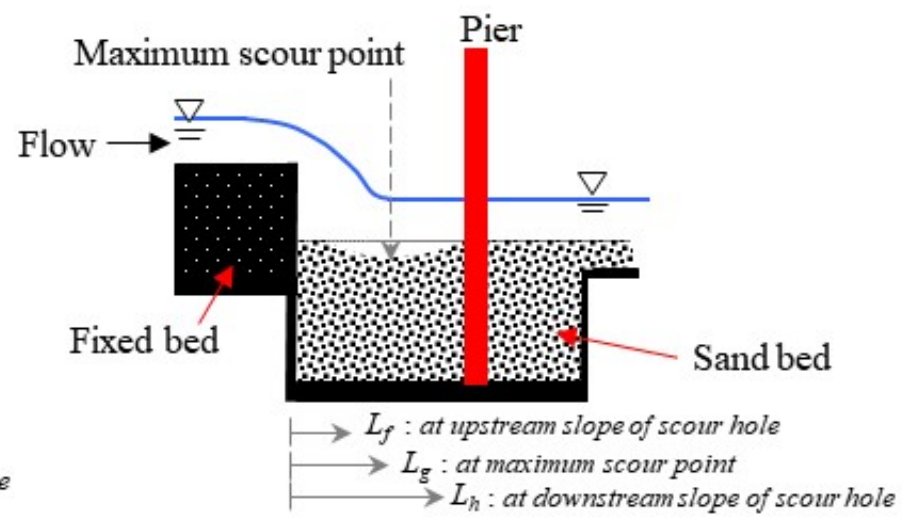

Distance of Pier $\left(L_{i}\right)$

Figure 4. Schematic graphs of the pier locations: (a) Free overfall condition. (b) Submerged overfall condition. 


\section{Observations from the Experiment and Discussion}

\subsection{Profile of the Scouring Development of Free Overfall without the Effect of the Pier}

In Figure 5, the time history of profile of scouring development in the case of free overfall w/o a pier is shown.

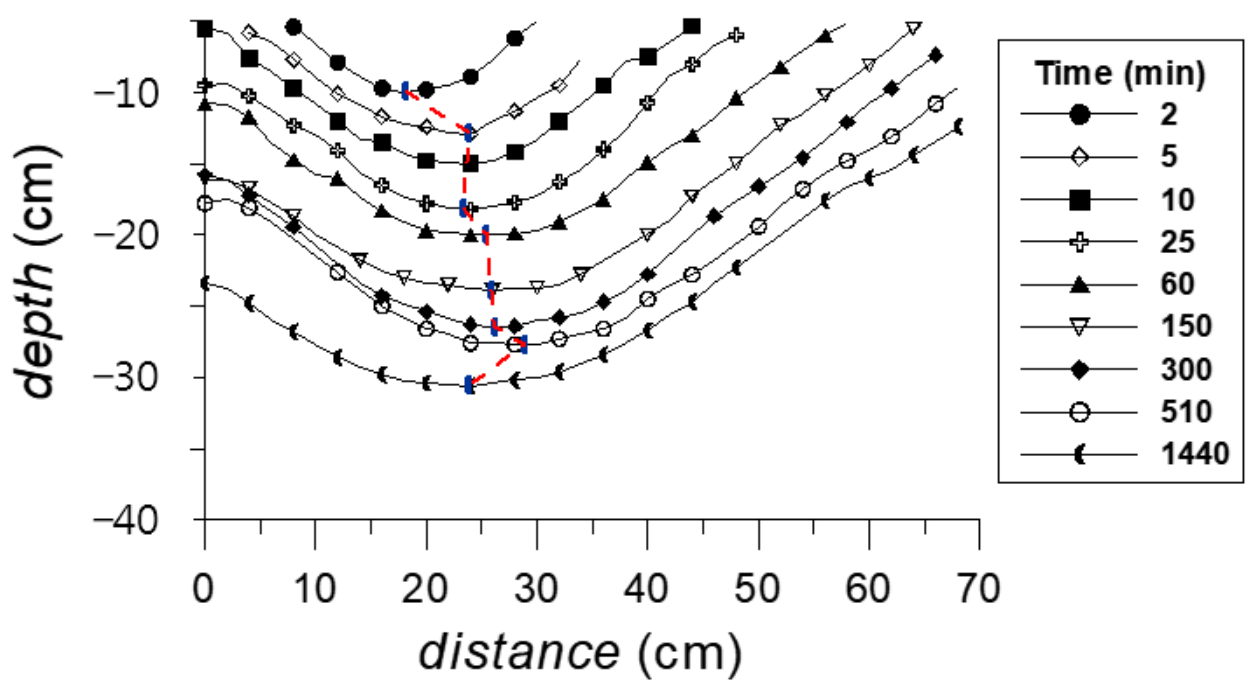

Figure 5. Development of the scouring process in the case of free overfall $\mathrm{w} / \mathrm{o}$ a pier.

The horizontal axis represents the direction of flow, 0 is at the location of the flowcontrol structure, the vertical axis is the scouring depth, and the broken red line in the figure links the maximum scour depth at each observed time. We investigated that the maximum scour depth moved deeper and more downstream. During the scouring process, we also found that the slope of the scouring hole sometimes fell backward toward the scouring hole. Two counter-rotation eddies that were produced by the overfall affected the slope of the scouring hole where the slope at upstream was less steep than the slope at downstream because the counter-rotating eddies downstream were stronger than the ones that rotated upstream. The eddy provided the drag force along the slope surface, which increased the resistance of the sediment fall due to gravity.

The mechanism of development of the scouring hole was that the two counter-rotating eddies brought up the sediment to the slope at the downstream side, and gradually a small dune was formed. Euler et al. (2014) investigated the mechanism using a tracer, which allowed a visualization of the turbulent eddying and was similar to the observations in our experiments [19]. While a deeper and wider scouring hole was dug by the overfall, the dune was moved further downstream. On the other hand, the sediment of the slope of the scouring hole upstream occasionally slid into the hole while the hole was being dug wider and deeper. The sliding sediment was brought away downstream randomly. The slope at the downstream of the scouring hole was steeper than the original at-rest angle of the sediment deposits because the eddies provided a floating force along the slope surface that supported the sediments to stay at the same location until slope instability due to the occurrence of toe erosion induced by scour.

The maximum equilibrium scour depth was about $26.7 \mathrm{~cm}$ at $1440 \mathrm{~min}$ in the condition of free overfall w/o pier as shown in Figure 5. Many researchers proposed different empirical formulas for the maximum equilibrium scour depth under varied conditions of structure, sediment material, and approach flow [2,8-11,21,24,29]. For the condition of free overfall, Mason and Arumugam (1985) mentioned that the empirical formula for the maximum equilibrium scour depth has general form.

$$
d_{s}=\alpha_{1} \frac{V^{\alpha_{2}} H^{\alpha_{3}}}{D_{50}^{\alpha_{3}}}
$$


in which $\alpha_{1}, \alpha_{2}, \alpha_{3}$, and $\alpha_{4}$ are all coefficients [8]. These coefficients were represented by different values in individual studies, and our study lists some suggested values from Mason and Arumugam (1985) in Table 2 [8]. In the procedure of the experiment work, the approach velocity $(V)$ was $15.9 \mathrm{~cm} / \mathrm{sec}$, the value of $H$ was $7.9 \mathrm{~cm}$ in the condition of free overfall, and the median diameter $\left(D_{50}\right)$ of sediments was $0.46 \mathrm{~mm}$. The comparison of the equilibrium scour depth in the experiment and with the empirical formulas of other authors can be obtained in Table 2. These results illustrated that the scour depth had close to an equilibrium state in the experiment.

Table 2. Coefficients for use in Equation (2) (Mason and Arumugam) [8].

\begin{tabular}{ccccccc}
\hline Author (year) & $\alpha_{\mathbf{1}}$ & $\alpha_{\mathbf{1}}$ & $\alpha_{\mathbf{1}}$ & $\boldsymbol{\alpha}_{\mathbf{1}}$ & $\boldsymbol{d}_{\boldsymbol{s}}(\mathbf{m})$ & Error $(\mathbf{m})$ \\
\hline Hartung (1959) & 1.4 & 0.64 & 0.36 & 0.32 & 0.222 & -0.045 \\
Chee and Kung (1974) & 1.663 & 0.6 & 0.2 & 0.1 & 0.359 & 0.092 \\
Machado (1980) & 1.35 & 0.5 & 0.3145 & 0.0645 & 0.255 & -0.012 \\
INCYTH (1981) & 1.413 & 0.5 & 0.25 & 0 & 0.299 & -0.032 \\
\hline
\end{tabular}

\subsection{Interaction between Piers and Overfall-Induced Erosion in Plain View}

\subsubsection{Free Overfall Impact on Pier at Different Location}

Regarding free overfall, there were five locations in the experiment as shown in Figure 6. Figure 6a shows the case where no pier was installed in the experiment, and we observed that the geographic changes in the flume were mostly two-dimensional except at the boundaries. The distance of the maximum scour depth was about $32 \mathrm{~cm}$, and the distance to the original bed level was about $80 \mathrm{~cm}$.
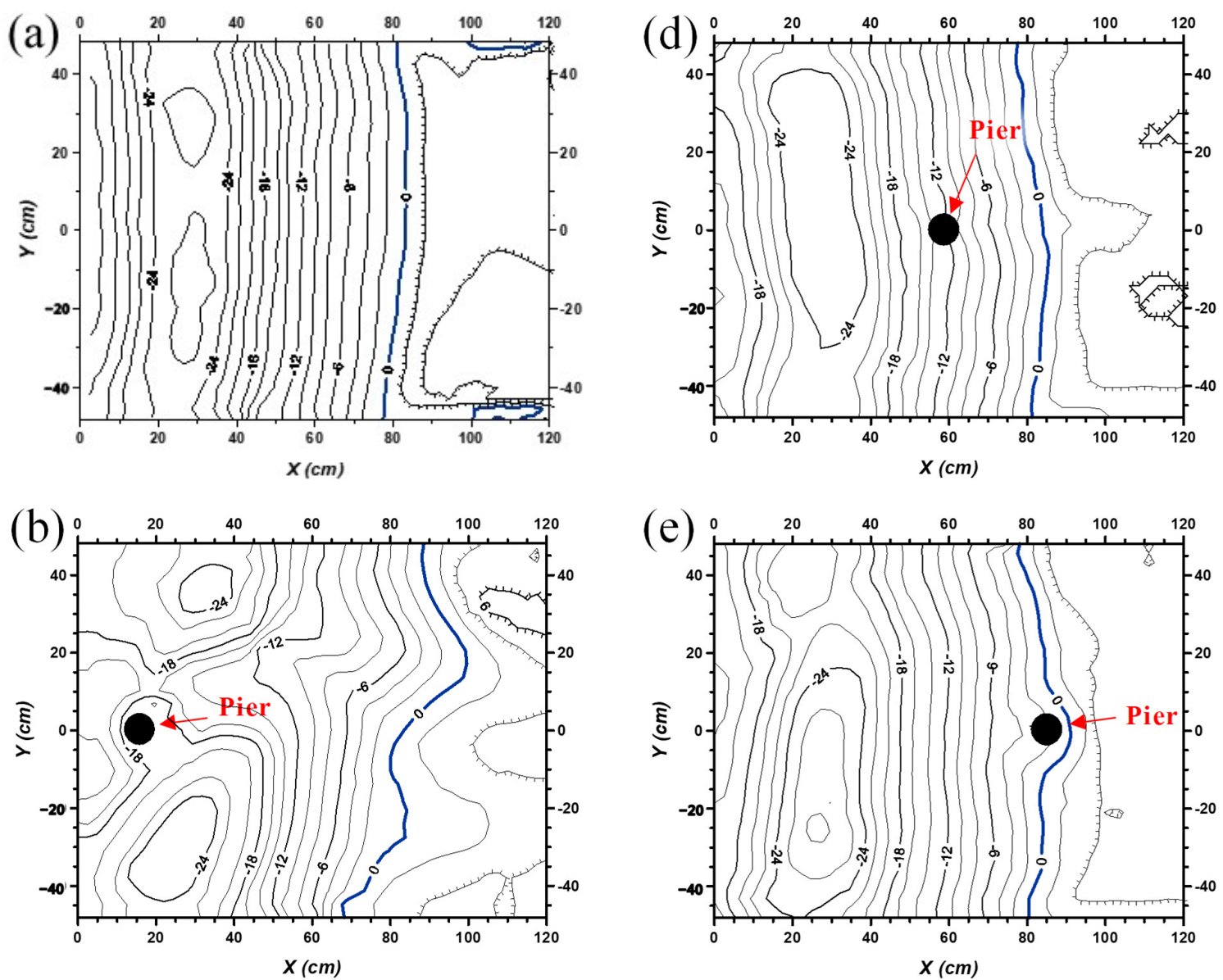

Figure 6. Cont. 
(c)

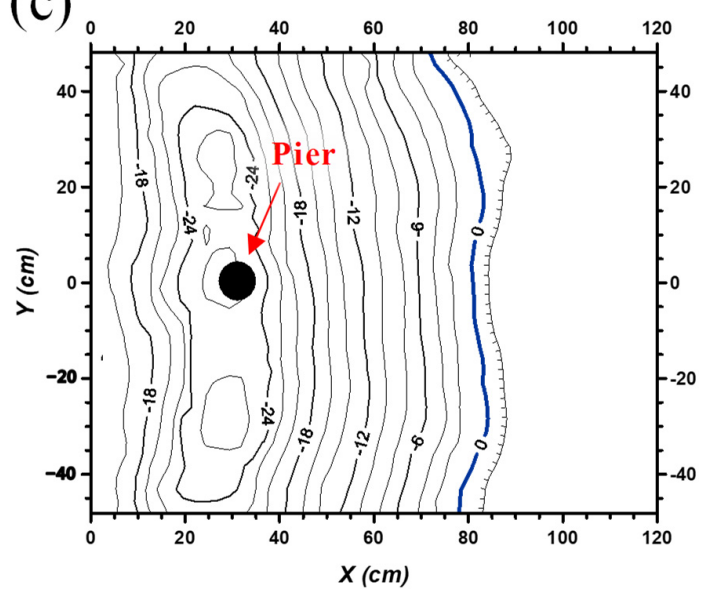

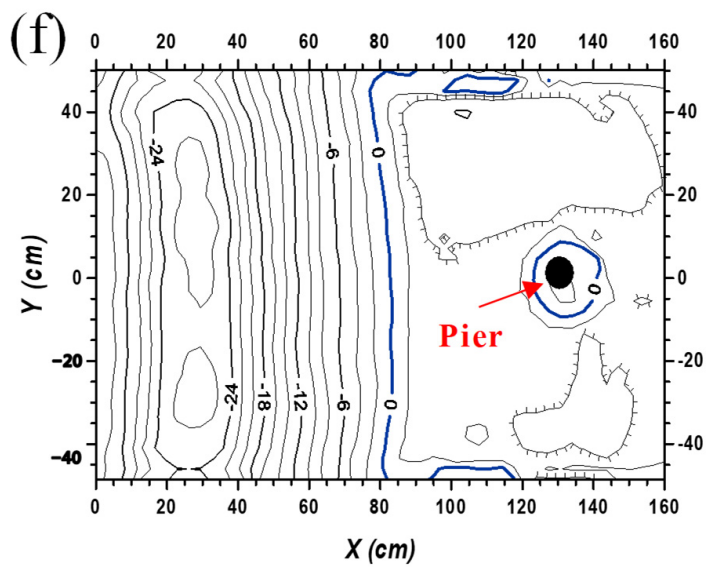

Figure 6. Contour lines of the river bed in the free overfall condition: (a) Free overfall w/o pier; (b) Case A; (c) Case B; (d) Case C; (e) Case D; (f) Case E.

Figure $6 \mathrm{~b}$ shows the results of Case A where the location of the pier was upstream of the scouring hole. In this case, the nappe directly impacted onto the pier instead of the river bed. The neighborhood of the pier was influenced by the pier and, therefore, deformed largely. Two sides of the pier were further eroded than in the previous case because the circulating flow took place after the nappe hit on the pier and the flow increased the erosion. However, the energy of the nappe reduced after hitting the pier, and thus less erosion occurred to the downstream.

Figure 6c shows Case B where the pier was located at the location of the maximum scour depth. A similar geography to the case without piers was observed, and therefore we concluded that the erosion induced by the pier in this case was not influential.

Figure $6 \mathrm{~d}$ or $6 \mathrm{e}$ demonstrate a slight change of the river bed near the pier (Case $\mathrm{C}$ and D). Figure $6 \mathrm{f}$ shows that the erosion took place only at the neighborhood of the pier while the pier was located at the deposition area (Case E).

Overall speaking, in the free overfall condition, when the pier location was upstream of the scouring hole $\left(L_{a}\right)$, significant erosion was found in the front of the pier along with a significant deposition in the back. When the pier location was far from the local scour $\left(L_{e}\right)$, some erosion and deposition took place in the front of the pier and in the back of the pier, respectively. The localized scour in the vicinity of the pier was induced by the approaching flow similar to classical local scour at the bridge (Dey 2014) [13]. When the pier location was at the edge of the local scour $\left(L_{d}\right)$, the erosion depth in the front was lower than the original river bed, and the erosion took place in the back of the pier as well. However, the eroded river bed level was still higher than the original bed.

As to the above discussions, while the pier location was at the downstream slope of the scour hole $\left(L_{c}\right)$, the erosion in the front of pier was similar to the case of free overfall $\mathrm{w} / \mathrm{o}$ pier. This indicates that the pier did not affect the characteristics of erosion. However, significant deposition occurred in the back of the pier in this case, and this caused the total erosion to be reduced. When the pier location was at the maximum scour point $\left(L_{b}\right)$, greater erosion took place compared with at the maximum scouring depth, and slight deposition occurred in the back of the pier.

\subsubsection{Submerged Overfall Impact on Piers at Different Locations}

Figure 7a shows that, in the case of submerged overfall without pier installation, the erosion was much less than in the case of free overfall, and the major scouring area was moved downstream. In Case F with the pier located upstream of the scour hole $\left(L_{f}\right)$, Figure $7 \mathrm{~b}$ shows that no significant geography changes of the river bed in the front of pier were found when comparing with the previous cases. However, significant deposition was observed at the back of the pier. When the pier location was at the maximum scouring 
depth (Case $\left.G, L_{g}\right)$, the erosion in the front of pier became much more significant compared with the previous case, and it decreased in the back of pier in Figure 7c. In this case, the maximum scour depth shows a significant increase. In Figure $7 \mathrm{~d}$, the overfall condition shows a limited impact on the pier in Case $\mathrm{H}\left(L_{h}\right)$.

(a)
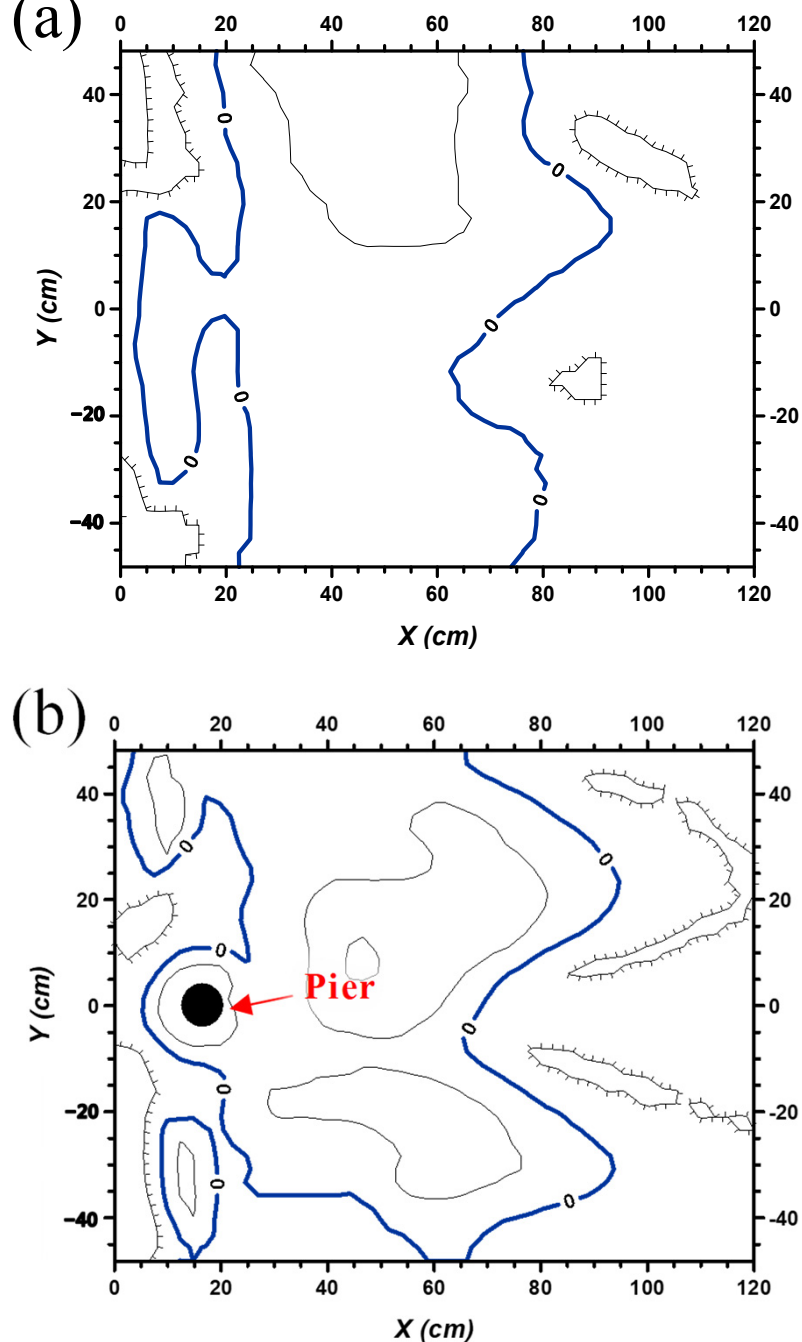
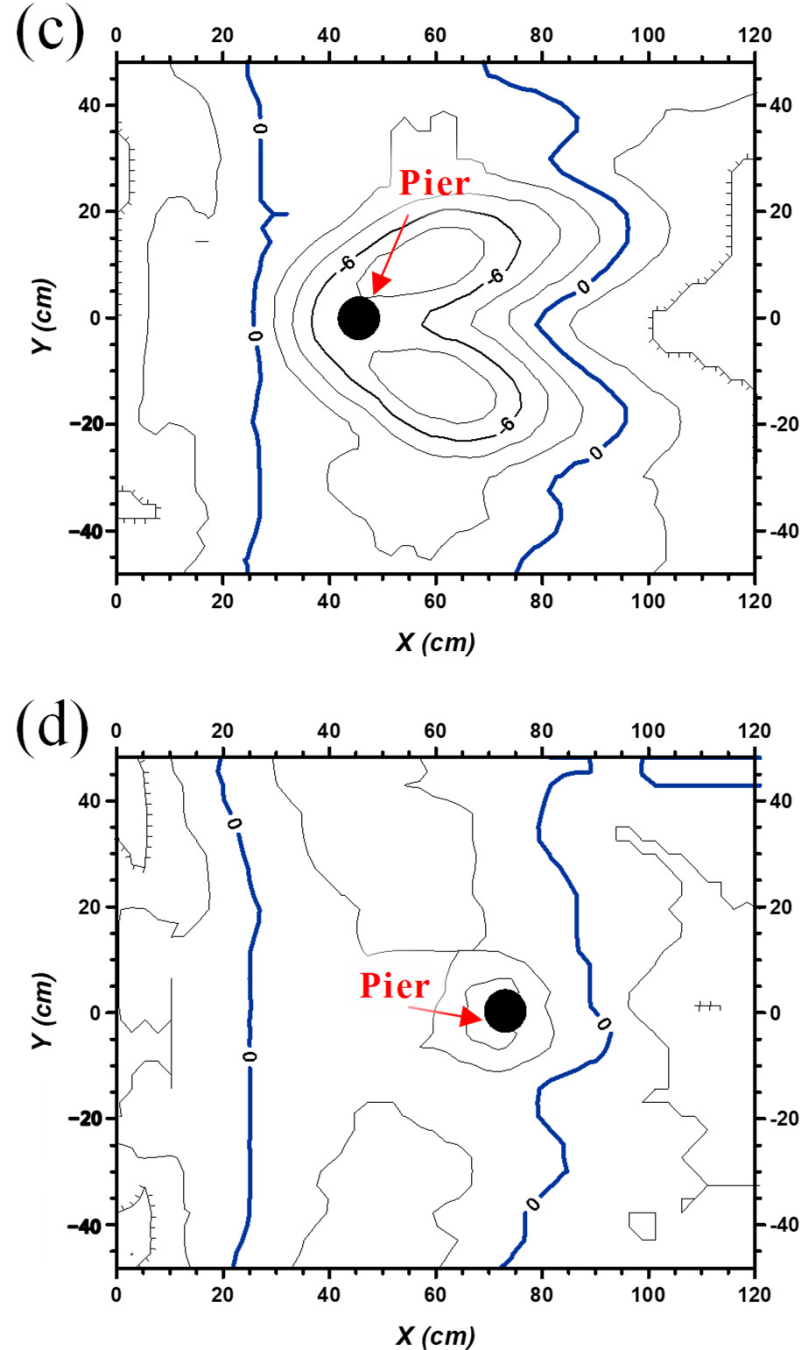

Figure 7. Contour lines of the river bed in the submerged overfall condition: (a) Submerged overfall w/o pier; (b) Case F; (c) Case G; (d) Case H.

Overall, in the submerged overfall condition, the scouring depth was clearly much smaller than in the free overfall cases. The most significant result was in Case G.

\subsection{Interaction between Piers and Overfall-Induced Erosion in Side View}

The profile change of the center line of the river bed can be seen in Figure 8. This demonstrates that there was no significant change of the landforms at the location in the front of pier when the water drop induced scour located upstream (Case A). The situation is similar to the case of the free overfall $\mathrm{w} / \mathrm{o}$ pier. However, a relatively large deposition was observed in the back of pier for the pure water drop scour condition (Case A). This condition presented increased scour depth due to the pier when the pier was located at the maximum erosion depth of the flow drop hole (Case B). A relatively larger scour to pure water drop condition but no significant deposition was observed when the pier was located at the downstream slope of the scour hole (Case C). When the pier was located far from the scour hole, a localized scour was found in the front of the pier, and some deposition was also observed in the back of the pier (Case E). Case D presented the pier located at the edge 
of the scour hole scour hole, and the erosion occurrence in the front of pier became more significant and lower than the initial bed level. On the other hand, erosion in the back of pier took place as well. However, the river bed level was still higher than the initial river bed level.

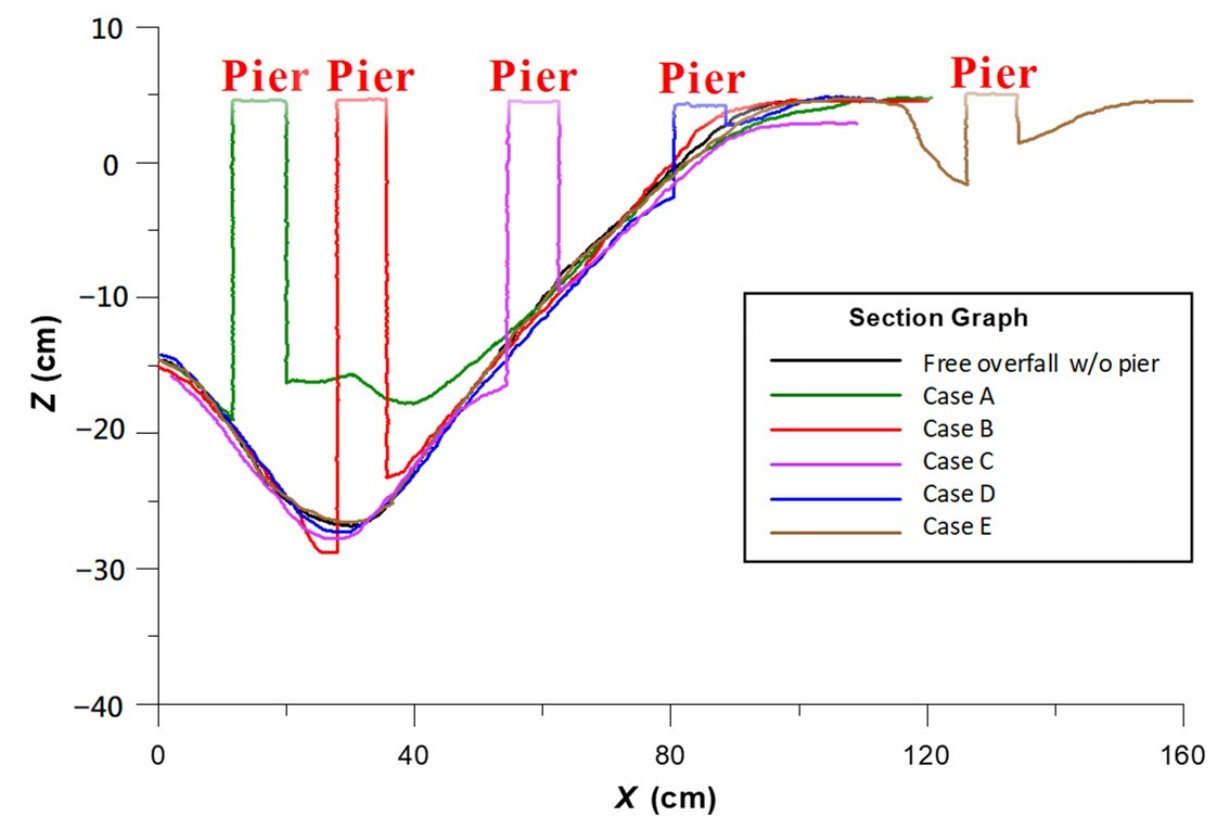

Figure 8. Comparisons of the center line of the vertical profile of the channel in the free type overfall drop.

We concluded that, while the pier located at the upstream slope of the maximum scour depth was induced by overfall, the scour that occurred in the front of pier was similar to the pure water drop inducing scour, which indicates that the scouring characteristic was not influenced by the pier. However, a significant deposition was observed in the back of pier. This revealed that the total scouring was reduced. This implies that better protection for the river bed can be found compared with the case of free overfall $\mathrm{o} / \mathrm{w}$ pier when the pier is located at the upstream slope of the scour hole.

When the pier was located at the downstream slope of the scour hole, an increased scour depth was found in the front of pier when compared with the original scour hole, and some deposition was observed at the back of pier. The experiments demonstrated that the change in depth of the river bed was at the minimum when the pier was located at the edge of the scour hole. When the pier was located far from the scour hole, a localized scour in the vicinity of pier was induced by the approaching flow without the impact of free overfall. These results imply that that the bridge pier was more secure when it was located at the edge of the scour hole.

The scour depth in the submerged overfall condition was found to be smaller than in the free overfall condition as shown in Figure 9. When the pier was located upstream of the maximum scour point (Case F), a deeper scour was found in the front of pier compared with the initial river bed, and there was a deposition at the back of pier. When the pier was located at the point of maximum scour (Case G), a significant scour was observed in the front and the back of the pier, and this was also deeper than for the initial river bed. When the pier was located in the initial river bed $($ Case $\mathrm{H})$, scour was found at the front and back of the pier and was smaller than in Case G. 


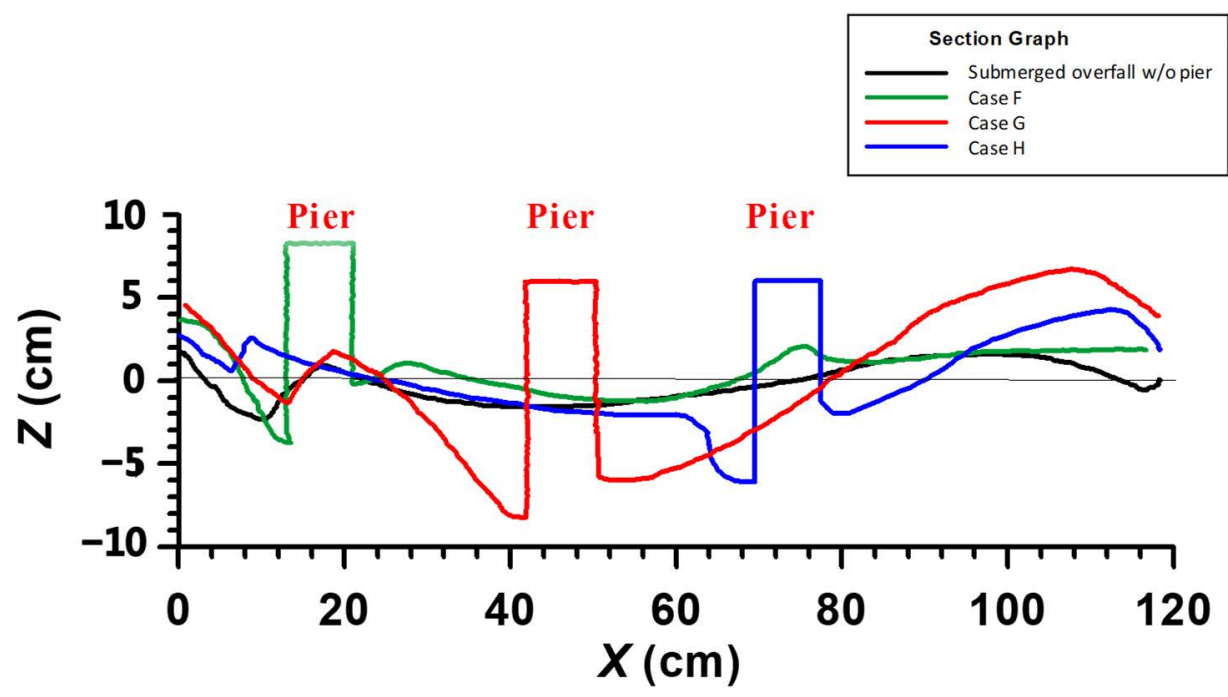

Figure 9. Comparisons of the center line of the vertical profile of the channel in the submerged type overfall drop.

We concluded that the scouring characteristics would be varied with the pier locations at the scour hole and that the most significant scour was found at the point of the maximum scour location induced by water drop. This implies that the bridge pier was a smaller influence of the local scour when it was closer to the location of the submerged overfall.

The maximum scour depth and its location change due to the interaction between overfall type and pier's location can be investigated based on our experiments. The pier's location $\left(L_{i}\right)$, the maximum scour depth $\left(d_{s}\right)$, and its location $\left(L_{s c o u r}\right)$ in each experiment were listed in Table 3. By comparing the conditions with and without pier, $d_{s} / d_{o-s}$ and $L_{\text {scour }} / L_{0-\text { scour }}$, the effect of pier's location on the maximum scour depth and its location can be investigated. In the condition of free overfall, when $L_{i}>L_{0-\text { scour }}$, the maximum scour depth and its location due to drop structure were not affected by the pier. When $L_{i}<L_{0-\text { scour }}$, the location of maximum scour depth was changed according to $L_{i}$, and the maximum scour depth became smaller than in the case of $w / o$ pier. In the condition of submerged overfall, when $L_{i}>L_{0-\text { scour }}$, the location of maximum scour depth was changed based on $L_{i}$, and the maximum scour depth was larger than in the case of w/o pier obviously. This result implied that the empirical formulas for the characteristic of local scour due to the drop structure, i.e., Mason and Arumugam (1985) [21], could be used when the overfall condition is free type and $L_{i}>L_{0-\text { scour }}$.

Table 3. Maximum scour depth and its location change due to the overfall type and pier's location.

\begin{tabular}{cccccc}
\hline Experiments & $\boldsymbol{L}_{\boldsymbol{i}} \mathbf{( \mathbf { c m } )}$ & $\boldsymbol{d}_{\boldsymbol{s}}(\mathbf{c m})$ & $\boldsymbol{L}_{\text {scour }}(\mathbf{c m})$ & $\boldsymbol{d}_{\boldsymbol{s}} / \boldsymbol{d}_{\boldsymbol{o}-\boldsymbol{s}}$ & $\boldsymbol{L}_{\text {scour }} / \mathbf{L}_{\boldsymbol{o}-\text { scour }}$ \\
\hline Free overfall w /o pier & w/o pier & -26.7 & 29.2 & - & - \\
Case A & 16 & -18.7 & 11.7 & $70.2 \%$ & $40.0 \%$ \\
Case B & 32 & -28.8 & 28.2 & $107.9 \%$ & $96.5 \%$ \\
Case C & 58.7 & -27.8 & 29.6 & $104.3 \%$ & $101.2 \%$ \\
Case D & 85.5 & -27.2 & 28.2 & $101.8 \%$ & $96.5 \%$ \\
Case E & 130.8 & -26.5 & 29.2 & $99.4 \%$ & $100.0 \%$ \\
\hline Submerged overfall w/o & w/o pier & -2.3 & 10.7 & - & - \\
pier & 17.3 & -3.7 & 13.1 & $158.9 \%$ & $122.6 \%$ \\
Case F & 46.4 & -8.3 & 41.8 & $355.9 \%$ & $390.8 \%$ \\
Case G & 73.5 & -6.2 & 69.8 & $265.1 \%$ & $652.4 \%$ \\
Case H & & & & \\
\hline
\end{tabular}




\subsection{Scour Conditions at Pier Surroundings Due to Overfall}

In the condition that the flow drop depth $(Z)$ was set at $12 \mathrm{~cm}$, the model of the pier was positioned at five different locations in the experiment facility. The centerline of the vertical profile of the flow drop inducing scour was represented by Case A-E in this paper. We used a camera in the hollow pier model to record the process of the experiment tests over $5 \mathrm{~h}$, and Figure 10 shows the scour depth of the surroundings of the pier in the condition of free overfall. In the same way, a model of pier was positioned at three different locations in the condition of submerged overfall and represented by Case F-H in the centerline of the vertical profile of the flow drop inducing scour. Figure 11 depicts the sour depth of the surroundings of the pier in the condition of submerged overfall. In Figures 10 and 11, the position of the pier at 0 degrees is the location where the approaching flow hits the pier.
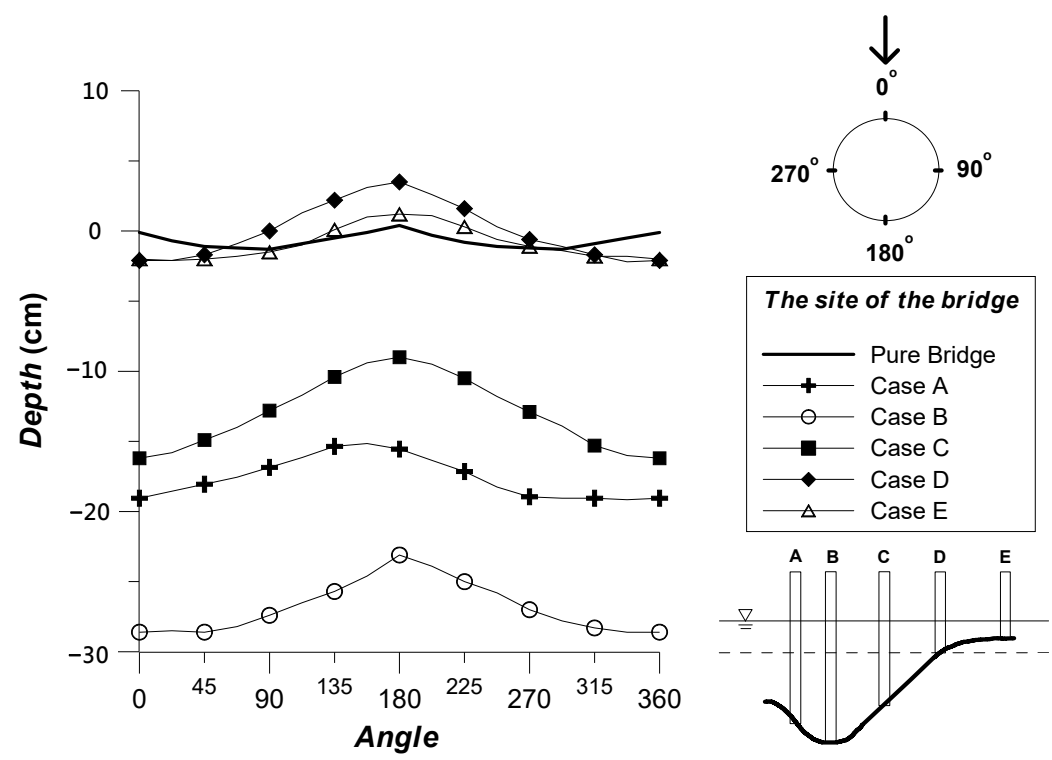

Figure 10. Scour depth distributions of the pier's surroundings in the free type of overfall drop.
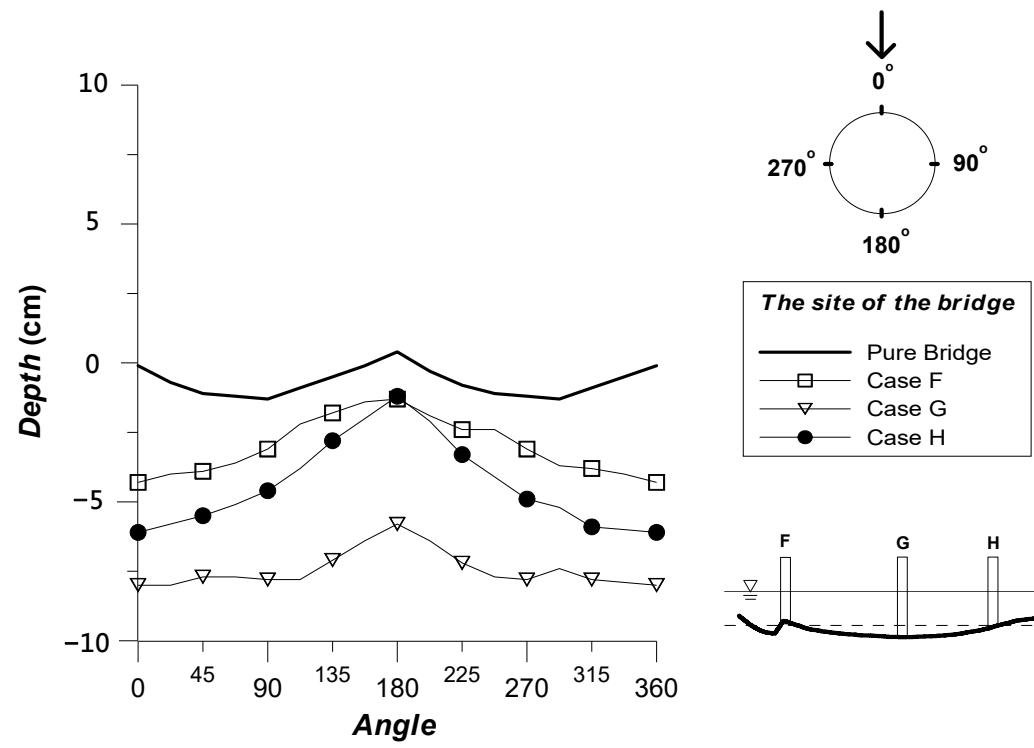

Figure 11. Scour depth distributions of the pier's surroundings in the submerged type of overfall drop. 


\subsubsection{Scour Conditions at the Pier Surroundings Due to Free Overfall}

Figure 10 shows that, in Case A, although the location of the pier was at the upstream slope of the scour hole, the bottom of the pier was scoured due to a reversed flow induced by the flow drop. The maximum scour point of the surroundings of the pier was at the position of 0 degrees. This reveals that a water jet along the river bed from upstream dominated the scour characteristics. There was an unstable condition at 90 degrees and 270 degrees due to interactions from the reversed flows and water jet from upstream, which led to an asymmetric scour at the surroundings of the pier. In Case B, when the pier was located at the point of the maximum scour, the water jet lost most of its energy after hitting the river bed; therefore, the scour depth located from 0 degrees to 45 degrees on the upstream side was almost the same.

The deposition, found in the downstream, was out of 45 degrees, and it deposited greater at around 60 degrees and scoured the least at 180 degrees. In Case C, we found that the scour distribution curve of the pier's surroundings appeared to be greatly affected by the pier inducing scour. However, this was not true, in fact, as the occurrence of the scour mostly occurred upstream of the scour hole. Cases D and E presented cases with the location of the pier at the edge of the scour hole and far from the scour hole. We found that Case D was affected by the sediment loaded flow from the bottom of the scour hole, and therefore, the local scour in front of the pier was not apparent. The scour hole in front of the pier in Case E, on the other hand, was mostly dominated by the pier itself, as the location of the pier in this case was away from the flow drop induced scour hole.

\subsubsection{Scour Conditions at the Pier Surroundings Due to the Submerged Overfall}

Figure 11 shows that, in Case F, the pier was located in the deposited mound and was hit by a submerged flow jet directly. The results show a full scour hole developed right after the deposited mound was affected by the overfall surrounding the pier, and was not found to be strongly affected by the water jet. In Case G, no significant landform was found in the pier's surrounding, we found in Figure 7c that scour holes developed with a shape of mullet roe surrounding the pier. Both depths in the holes were found to be greater than the ones in front of the pier. This indicates that the water jet caused by the submerged overfall in the $x$ direction was stronger than in the $z$ direction. In Case $\mathrm{H}$, the pier was located downstream of the scour hole, and therefore a greater range of landforms could be observed.

\section{Conclusions}

This paper focused on probing the mechanism of the scouring effect on piers considering different bridge locations and the flow drop induced scour hole through a series of experiments. Two types of overfall, submerged and free overfall, were applied in the experiment. This mechanism is expected to draw attention from both engineering and academic specialists regarding protecting bridges in newly changed landforms.

Our concluding remarks can be drawn as follows:

Location of the pier vs. the free overfall:

1. The scour surrounding bridge pier in the free overfall condition was mainly controlled by the overfall.

2. When the pier's location was at the upstream slope of the scour hole, better protection to the river bed was found compared with the case of the free overfall $\mathrm{w} / \mathrm{o}$ pier.

3. When the pier's location was at the maximum scouring point in the scour hole, this deepened the scour depth in the front of pier in a limited manner. Reconstructed bridge piers should not be located here.

4. When the pier's location was at the downstream slope of the scour hole, the pier did not clearly change the impact of the free overfall on the river bed. However, the depth of scour at the vicinity of the bridge pier was still deep enough to expose the pillar in the approaching flow. 
5. When the pier's location was at the edge of the scour hole, the scour depth that occurred in front of the pier was similar to the case of the submerged overfall $\mathrm{w} / \mathrm{o}$ pier. The depth of the localized scour at the vicinity of the bridge pier was the minimum under the interaction between the free overfall and the scour at the bridge pier. This implies that a reconstructed bridge pier would be more secure here.

6. When the pier's location was far from the local hole, the localized scour surrounding the bridge pier was induced by the approaching flow only and without the influence of the free overfall.

Location of pier vs. submerged overfall:

1. Scour at the pier's surroundings was dominated by the flow drop inducing jet, and a relatively deeper scour was be developed due to water jets that were closer to the river bed. This implies that a reconstructed bridge pier should not be located in the area influenced by the submerged overfall.

2. The most significant scour depth at the front of pier was investigated in the condition where the pier location was at the maximum scour point induced by the submerged overfall. A reconstructed bridge pier should not be located here.

3. When the pier was at the maximum point of scour, it induced more scour hole development due to the disturbances caused by the water jet and pier. The depth of those scour holes would be even larger than the scour depth at the pier's surrounding.

Author Contributions: Conceptualization, C.-K.H. and C.-W.L.; methodology, C.-K.H. and C.-W.L.; formal analysis, C.-K.H., C.-W.L., and W.-L.L.; C.-W.L. and W.-L.L. wrote the manuscript, and all authors contributed to improving the paper. All authors have read and agreed to the published version of the manuscript.

Funding: This research received no external funding.

Institutional Review Board Statement: Not applicable.

Informed Consent Statement: Not applicable.

Data Availability Statement: Data sharing not applicable.

Acknowledgments: We thank the reviewers for their useful comments and suggestions.

Conflicts of Interest: The authors declare no conflict of interest.

\section{References}

1. Dey, S. Bedforms. In Fluvial Hydrodynamics; GeoPlanet: Earth and Planetary Sciences; Springer: Berlin/Heidelberg, Germany, 2014; Available online: https:/ / doi.org/10.1007/978-3-642-19062-9_8 (accessed on 11 January 2021).

2. Schoklitsch, A. Kolkbildung unter Uberfallstrahlen. Wasserwirtschaft 1932, 24, 341-343.

3. Gill, M.A. Hydraulics of rectangular vertical drop structures. J. Hydraul. Res. 1979, 17, 289-302. [CrossRef]

4. Little, W.C.; Murphey, J.B. Model study of low drop grade control structures. J. Hydraul. Div. 1982, 108, $1132-1146$.

5. Moore, W.L. Energy loss at the base of free overfall. Trans. ASCE 1943, 108, 1343-1360.

6. Rand, W. Flow geometry at straight drop spillways. Proc. ASCE 1955, 81, 1-13.

7. Smith, C.D.; Strang, D.K. Scour in stone beds. In Proceedings of the 12th IAHR-Congress, International Association for Hydraulic Research, Delft, The Netherlands, 11-14 September 1967.

8. Mason, P.J.; Arumugam, K. Free jet scour below dams and flip buckets. J. Hydraul. Eng. 1985, 111, 220-235. [CrossRef]

9. Hoffmans, G.J.C.M. Jet scour in equilibrium phase. J. Hydraul. Eng. 1998, 124, 430-437. [CrossRef]

10. Hoffmans, G.J. Closure problem to jet scour. J. Hydraul. Res. 2009, 47, 100-109. [CrossRef]

11. D'Agostino, V.; Ferro, V. Scour on alluvial bed downstream of grade-control structures. J. Hydraul. Eng. 2004, 130, 24-37. [CrossRef]

12. Yager, E.M.; Dietrich, W.E.; Kirchner, J.W.; McArdell, B.W. Prediction of sediment transport in step-pool channels. Water Resour. Res. 2012, 48. [CrossRef]

13. Melville, B.W. Scour at various hydraulic structures: Sluice gates, submerged bridges and low weirs. Australas. J. Water Resour. 2014, 18, 101-117. [CrossRef]

14. Breusers, H.N.C.; Nicollet, G.; Shen, H. Local scour around cylindrical piers. J. Hydraul. Res. 1977, 15, 211-252. [CrossRef]

15. Ahmed, F.; Rajaratnam, N. Flow around bridge piers. J. Hydraul. Eng. 1998, 124, 288-300. [CrossRef]

16. Graf, W.H.; Istiarto, I. Flow pattern in the scour hole around a cylinder. J. Hydraul. Res. 2002, 40, 13-20. [CrossRef] 
17. Dey, S.; Raikar, R.V. Characteristics of horseshoe vortex in developing scour holes at piers. J. Hydraul. Eng. 2007, 133, 399-413. [CrossRef]

18. Ataie-Ashtiani, B.; Aslani-Kordkandi, A. Flow field around single and tandem piers. Flow Turbul. Combust. 2013, 90, 471-490. [CrossRef]

19. Euler, T.; Zemke, J.; Rodrigues, S.; Herget, J. Influence of inclination and permeability of solitary woody riparian plants on local hydraulic and sedimentary processes. Hydrol. Process. 2013, 28, 1358-1371. [CrossRef]

20. Baker, C.J. Vortex Flow around the Bases of Obstacles. Ph.D. Thesis, University of Cambridge, Cambridge, UK, 1979. Available online: https:/ / doi.org/10.17863/CAM.14045 (accessed on 11 January 2021).

21. Baker, C. Theoretical approach to prediction of local scour around bridge piers. J. Hydraul. Res. 1980, 18, 1-12. [CrossRef]

22. Chabert, J.; Engeldinger, P. Etude des Affouillements Autour des Piles des Ponts; Laboratoire National D'hydraulique: Chatou, France, 1956.

23. Chee, R.K.W. Live-Bed Scour at Bridge Sites. Master's Thesis, Auckland University, Auckland, New Zealand, 1982.

24. Chiew, Y.M.; Melville, B.W. Local scour around bridge piers. J. Hydraul. Res. 1987, 25, 15-26. [CrossRef]

25. Melville, B.W. Live-bed scour at bridge piers. J. Hydraul. Eng. 1984, 110, 1234-1247. [CrossRef]

26. Elliott, K.R.; Baker, C. Effect of pier spacing on scour around bridge piers. J. Hydraul. Eng. 1985, 111, 1105-1109. [CrossRef]

27. Melville, B.W.; Chiew, Y.-M. Time scale for local scour at bridge piers. J. Hydraul. Eng. 1999, 125, 59-65. [CrossRef]

28. Sheppard, D.M.; Odeh, M.; Glasser, T. Large scale clear-water local pier scour experiments. J. Hydraul. Eng. 2004, 130, 957-963. [CrossRef]

29. Ataie-Ashtiani, B.; Beheshti, A.A. Experimental investigation of clear-water local scour at pile groups. J. Hydraul. Eng. 2006, 132, 1100-1104. [CrossRef]

30. Melville, B.W.; Coleman, S.E. Bridge Scour; Water Resources Publication: Highlands Ranch, CO, USA, 2000.

31. Richardson, E.V.; Davis, S.R. Evaluating Scour at Bridges; No. FHWA-NHI-01-001; Federal Highway Administration: Washington, DC, USA, 2001.

32. Khosronejad, A.; Kang, S.; Sotiropoulos, F. Experimental and computational investigation of local scour around bridge piers. Adv. Water Resour. 2012, 37, 73-85. [CrossRef]

33. Raudkivi, A.J.; Ettema, R. Effect of sediment gradation on clear water scour. J. Hydraul. Div. 1977, 103, $1209-1213$.

34. Melville, B.W.; Sutherland, A.J. Design method for local scour at bridge piers. J. Hydraul. Eng. 1988, 114, 1210-1226. [CrossRef] 